\title{
THE AMERICAN CREATIVITY OF FRANK FURNESS
}

ALAN HESS

$s$ an architectural historian of the American West, I have always been
drawn to the exuberance of the region's modern designs that hang from
poles, jut out from cliffs, border great highways, and disrupt the narrative of modern architecture as it has been written since the Museum of Modern Art's first exhibit on the International Style in 1932. The West was a region of tremendous growth and innovation in the twentieth century, just as, in the decades following the Civil War, the East had been. It was there, mostly east of the Mississippi River in the realm of the Pennsylvania Railroad, that Frank Furness helped lay the foundation that shapes modern American architecture as we know it today.

What does Frank Furness still mean to us? What were the circumstances that allowed him to see and creatively interpret, free of conventional biases, the forces at work in his day? How did similar approaches devised by other, later architects inspire significant modern architecture after him, even as his own work was largely ignored or misunderstood in the high art and architecture histories? The usual story historians tell about the birth of modern architecture sidetracked Frank Furness long ago. How could they have mistaken such a pivotal figure as a mere curiosity?

Furness grew his modernism not from speculative theories or blue-sky philosophy but from life as the industrial age was creating it all around him. His modern approach was just as much about technical innovations in engineering and construction as it was about the way modern factories and their products 
were reinventing the lives of people at all levels of society. Baldwin Locomotive Works' thousands of steam engines, manufactured in Philadelphia, and the Pennsylvania Railroad, headquartered and created in Philadelphia, tied the expansive nation together in a way that transformed both corporate commerce and family vacations. A thriving and democratic American economy was creating wealth, enlarging cities, and creating leisure time. Some of the most influential and culturally transformative companies of his day-the Apple, Microsoft, and Google of those times-were in Philadelphia, and their leaders were Furness's clients. Independent of history and disinterested in European fashion, Furness's Philadelphia was still the spiritual home of Ben Franklin, and quite willing to overthrow old traditions, fashions, or theories for a good reason. This was the modernity that Furness captured in his new architecture.

That pragmatic, reality-based spirit would never disappear from the course of modernism, especially in America; but like Furness's career, it wasn't usually reported in the standard histories. The legions of critics and historians documenting the rise of the Bauhaus in Europe in the 1920 s favored the European tradition of high art culture wherein academic theory had to underpin any architecture that was to be considered seriously. By the time New York's Museum of Modern Art spotlighted modern architecture's achievements in the 1932 International Style exhibit, the groundwork had been laid for the story of modernism as the province of an elite avant-garde. Even if these historians had heard of Furness (perhaps from reading the memoirs of Louis Sullivan, his one-time employee), his significance was not recognized. Ensconced in New York, Paris, or London, they were unprepared to see how modern life, in all its phases, had developed in unheralded Philadelphia and how its industrial design, technologies, and values had shaped Furness's designs. Reflecting the multiplying power of the commercial economy, the raw power of technology, and the desires and needs of the popular audience, Furness generated forms and solutions that would usually rile the critics as crude, exaggerated, and (from their educated perspective) tasteless. Later critics would have a similar response.

When modernist historians began to look back to find the roots of modernism, Furness appeared to be a fussy historicist Victorian - exactly what modern architecture was meant to overthrow. George Thomas's text correctly identifies Furness as the very embodiment of his modern times. He drew upon the pistons, the raw combination of forms and functions of locomotive designs, the factory skylights, the towering and emblematic smokestacks, and the energetic commercial districts that were as much a part of the Age of Furness as columns and pediments were part of the Age of Pericles. 
Furness's approach, incorporating the new materials and the new technologies of his day and making forms to meet specific purposes, would be repeated again and again in the actual course of modern architecture-as it was built and lived in, not just as it was reported in history books and journals—reflecting the symbiotic relationship between modern architecture and modern society that persisted through the next century. The most remarkable results that appeared in commercial buildings and resorts would rarely be noticed, or praised, by critics and historians following the mainstream narrative. They would often be controversial. Yet they are essential to modernism.

Furness's impact on two of his employees, Louis Sullivan and William Price, demonstrated the immediate revolutionary effect of the way he drew on a real, rather than a theoretically idealized, modern life. Sullivan gave shape to the modern office building, a practical architectural tool that improved commerce by combining new steel frame and elevator technologies to create appealing efficiencies and densities. Like Furness, Sullivan saw an artistic expression in this new way of life. Will Price responded to the way Philadelphia's modern industrial economy created wealth and leisure time for a broad cross section of the public by designing magnificent resorts in Atlantic City, where his Traymore Hotel (1914-1915) unleashed the verticality and ahistoricism of so-called American Vertical Style, which Price's firm called the modern style.

The impact of Furness's clear-eyed look at new conditions continued into the next generation. Frank Lloyd Wright, Sullivan's employee, designed suburban homes to reflect a new, more informal way of living that embraced nature, while opening his plans to include the housewife, breaking down old hierarchies and anticipating the future. The suburbs and their lifestyle were a direct consequence of new interurban rail (and later automobile) transportation systems that reshaped American cities as decentralized, multicentered urban areas that demanded their own new architecture-innovations that would continue into the later twentieth century.

Factories for heavy industry, commerce to disperse consumer goods to a middle-class population, suburban decentralization, automobiles: this was modernity as it was being lived. By reintroducing Furness into the narrative, George Thomas expands the history of modernism to allow us to see architecture today through a new set of landmarks, and forces us to reinterpret many of the old familiar landmarks. We can see the power and creativity this approach brought to modernism in the cities where the industrial culture of Philadelphia moved west along the lines of the Pennsylvania Railroad. In their pragmatism, and their creative embrace of technological advances fueled by commercial wealth and 
social advances, Detroit, Chicago, and Los Angeles followed in Philadelphia's footsteps.

In Detroit, Albert Kahn's factories were designed as carefully as clockworks, but built on an enormous twentieth-century scale that would inspire the young Walter Gropius, Ludwig Mies van der Rohe, and Richard Neutra. As Detroit's vibrant technologies, mass-produced consumer goods, and wealth grew and spread, they created the environment where the modern shopping mall was defined by Victor Gruen, and where Minoru Yamasaki and Eero Saarinen revitalized architecture at midcentury. Los Angeles took modern industry, modern commerce, modern media, and new ways of living to create a multicentered suburban metropolis, its new architecture shaped for automotive living on a mass basis. There, architect Wayne McAllister saw modern life as clearly in the I930s as had Furness in the I870s, and was equally unfettered by academic theories when he designed his extraordinary drive-in restaurants. The automobile was now the driving force behind commerce and the shape of the city, as the railroad had been in Furness's time. Automobiles forced a redefinition of urban space to accommodate cars and pedestrians; they demanded a bold architectural scale appropriate to the elongated distance of the commercial strip, and architects responded imaginatively. That scale required an integration of sign and architecture, symbol and meaning that acknowledged architecture's role as a form of urban communication. After 1945, Armét and Davis and other Los Angeles architects would continue this evolution by perfecting the modern coffee shops that served the car-mobile public with startling evocations of the modern age, much as Furness had done in the late nineteenth century in his small commuter rail stations. McAllister would follow Will Price's embrace of an architecture for mass leisure in Atlantic City in the I9ros by designing seminal hotel-casinos in Las Vegas in the I940s and 1950 .

Like Furness's buildings, these would be either ignored or excoriated by critics as lowbrow. They were seen as undisciplined and exaggerated parodies of the International Style purity that had become mainstream by the mid-twentieth century-or as simulacra of the automobiles that were viewed as wrecking the classic urban downtowns. Outrage was heaped upon Philadelphia architects Robert Venturi, Denise Scott Brown, and Steven Izenour when, in Learning from Las Vegas, they dared to acknowledge the profound ideas McAllister introduced in that city. Even well-known architects such as Yamasaki and Saarinen were subjected to similar criticisms. Like Furness, these architects saw the commercial energy and the technological advances of the times, used them to respond to the way the public at large lived, worked, and played - and were vilified or dismissed for it. 
By returning Frank Furness to his central position at the birth of modern architecture in America, George Thomas helps us understand the depth of the American roots of modernism. He enables us to see anew a range of building types and interpretations that critics in the intervening years had largely written out of the story: small boathouses as well as monumental rail terminals; branch bank buildings as well as museums and university libraries. High-art critics had dismissed these as commonplace, as not serious, as too commercial, as insufficiently pure in their rendition of architectural theory. They were not the exquisitely spare custom homes, the towering cubic and uninflected skyscrapers, the great temples of high culture that make up the majority of landmarks in the conventional canon of modern buildings, but which remain a tiny portion of the built environment. All of these buildings, whether high culture or popular, need to be part of the story of modernism. All of them are needed as a map for today's architects. Modernism is not one thing, it is many. It is not only minimalist and purist, it is colorful, opulent, ornamented. It is not only exquisitely customized and expensive, but popular and mass produced. It was not just elitist but commercial. It was not just the theoretically pure but the unlimited and exploratory. After all, modern architecture at its heart is an experiment, one that draws on the potency of technology and materials, lifestyles, and imagination.

Creating the very idea of modern architecture required Frank Furness's ability to see culture broadly and with fresh eyes (undoubtedly helped by his family's friendships with Ralph Waldo Emerson and Walt Whitman) and his bulldog determination to pull an entirely new view of architecture from the dynamic and unexpected social and technological forces at work in America after the Civil War. It came from his engagement with — not removal from-those forces. And he certainly did not allow convention, precedent, or elitist taste to blur his view of the raw material of the new culture.

By reclaiming Frank Furness's pivotal role in the development of modern architecture, we can now see the success of that real-world approach in his work, and in the later creative centers of modernity in Atlantic City, Chicago, Detroit, Los Angeles, Miami, and Las Vegas. George Thomas reminds us of how many significant turning points occurred when insights into contemporary life, culture, and technology became a springboard for creative design. His modernism-and Frank Furness's - is not merely a theory but a mirror held up to society. We can only wonder what Furness would have done with the forms of the rocket-styled automobile and the transformative imagination of Walt Disneybut the myriad progeny of his works and those of his students attest to the potency of the industrial age that continues to shape our times. 
